\title{
Properties of ß-lactamase from Neisseria gonorrhoeae
}

\author{
Marta C de Castillo ${ }^{+}$, Fernando Sesma, Olga M de Nader, \\ Aida P de Ruiz Holgado
}

Instituto de Microbiología, Facultad de Bioquímica, Química y Farmacia, Universidad Nacional de Tucumán, Ayacucho 471, (4000) S.M. de Tucumán, Argentina

$\beta$-lactamase activity was studied in Neisseria gonorrhoeae strains. Optimum temperature was found to be $37^{\circ} \mathrm{C}$. The enzyme was inactivated at temperatures higher than $60^{\circ} \mathrm{C}$, but remained active during storage at low temperatures $\left(4^{\circ} \mathrm{C},-30^{\circ} \mathrm{C}\right.$ and $\left.-70^{\circ} \mathrm{C}\right)$ for two months. Enzyme activity was observed within a $\mathrm{pH}$ range of 5.8-8.0, while the optimum $\mathrm{pH}$ was 7.0-7.2. Addition of $\mathrm{Ni}^{2+}, \mathrm{Fe}^{2+}, \mathrm{Fe}^{3+}, \mathrm{Mn}^{2+}$ and p-chloromercurybenzoate to the reaction buffer exerted a negative effect upon the activity, whereas $\mathrm{Hg}^{2+}$ and ethylene diamine tetra-acetic acid produced complete inhibition. These results would indicate the presence of -SH groups at the catalytic site of the enzyme.

Key words: Neisseria gonorrhoeae - b-lactamase - enzyme activity

Penicillin became the drug of choice for treatment of infections caused by Neisseria gonorrhoeae shortly after it became available for clinical use. Remarkably small doses (e.g., 100,000 units altogether) were used to cure gonorrhoea (Mahoney et al. 1945), an occurrence reflecting the high susceptibility of the gonococcus to penicillin (Reyn et al. 1958). During the subsequent decades a gradual increase in gonococcal resistance to penicillin, documented in the United States (Martin et al. 1970) and elsewhere (Amies 1969, Reyn 1961, 1969, Arya \& Phillips 1979), needed increases in the dose of penicillin as well as the addition of probenecid to maintain effective therapy (Holmes et al. 1973, Kaufman et al. 1976). In the United States, however, a reduction in gonococcal resistance to penicillin has been witnessed since 1972 (Reynolds et al. 1976), and in 1976 a substantial decline in the rate of increase in morbidity from gonorrhoea was observed (CDC 1977). The isolation of penicillinase-producing $N$. gonorrhoeae (PPNG) (Ashford et al. 1976, Phillips 1976) urged the use of other antimicrobials.

The first two reported cases of infection with PPNG in the United States were in March 1976 in Maryland and in April 1976 at Travis Air Force Base in California (CDC 1976).

In Argentina the isolations of PPNG strains reached a value of 30\% in 1995 (Mernes et al. 1997). The present work was carried out in order to characterize and to study the properties of $\beta$ -

\footnotetext{
${ }^{+}$Corresponding author. Fax: +54-81-248169

Received 11 August 1997

Accepted 15 January 1998
}

lactamase from $N$. gonorrhoeae as to contribute useful information.

\section{MATERIALS AND METHODS}

Microorganisms - Two strains of N. gonorrhoeae, isolated from clinical specimens, were used. The strains were maintained at $-70^{\circ} \mathrm{C}$ in a cryoprotective medium (Tryptic Soy Broth -BBLwith $25 \%$ glycerol). Strains were selected according to their capacity to produce $\beta$-lactamase.

Preparation of cell-free extracts - Portions of SJ-GC broth (not commercially avilable) $(500 \mathrm{ml})$ were inoculated and incubated at $37^{\circ} \mathrm{C}$ for $24 \mathrm{hr}$ (Shockley et al. 1980). Subsequent operations were carried out between 0 and $4^{\circ} \mathrm{C}$. Cells were harvested at the end of the log phase by centrifuging at $6,000 \mathrm{~g}$ for $20 \mathrm{~min}$, washed twice with phosphate buffer ( $\mathrm{pH}$ 7.0) and resuspended in the same buffer to give a final concentration of $30 \%$ wet weight $(\mathrm{w} / \mathrm{v})$. Cell suspensions were disintegrated in a French press at a constant pressure of 1,575 $\mathrm{kg} \mathrm{cm}^{-2}$. Cell debris was removed by centrifuging at $30,000 \mathrm{~g}$ for $10 \mathrm{~min}$. The supernatant fluid was used as crude enzyme extract.

Enzyme assays - ß-lactamase activity was determined by a direct spectrophotometric method (O'Callaghan et al. 1972). Haemophylus influenzae ATCC 10211 was used as a negative control, whereas Escherichia coli ATCC 35218 was used as a positive control. Hydrolysis of the $\beta$-lactamic ring was measured by the decrease of optic density of the cephaloridine solution. Measurements were carried out at $255 \mathrm{~nm}$. One enzyme unit (U) was defined as the amount of enzyme that released $1 \mu \mathrm{mol}$ of cephaloridine per $\mathrm{ml}$ per min under the given assay conditions. Specific activity was expressed as enzyme units per mg of protein. 
Protein concentration was determined by the method of Lowry et al. (1951) with bovine serum albumin (BSA) as a standard.

Isoelectric focusing - Electric focusing was performed on a sucrose ampholyte gradient $(\mathrm{pH} 3.0$ to 10.0). The experiment was carried out below $4^{\circ} \mathrm{C}$ on an ampholyte electric focusing column (LKB 8100) for $48 \mathrm{hr}$ with a final gradient of 300 $\mathrm{U}$. The contents of the column were cut out into 3 $\mathrm{ml}$ fractions and each fraction was assayed for its B-lactamase and $\mathrm{pH}$ (Matthew et al. 1975).

Determination of optimal $\mathrm{pH}$, temperature and thermal stability - The effect of the $\mathrm{pH}$ on the $\mathrm{B}$ lactamase activity was determined in phosphate buffer $\left(0.2 \mathrm{~mol} \mathrm{l}^{-1}\right)$ with a $\mathrm{pH}$ range of 5.8-8.0.

The influence of the temperature on the enzymatic activity was determined by incubating the assay mixture for $15 \mathrm{~min}$ at temperatures ranging from $15^{\circ} \mathrm{C}$ to $55^{\circ} \mathrm{C}$.

Thermal stability was determined by incubating the enzyme extract at temperatures ranging from $15^{\circ} \mathrm{C}$ to $60^{\circ} \mathrm{C}$ for 1 to $25 \mathrm{~min}$. Substrate was then added and the solution incubated for an additional $15 \mathrm{~min}$ at $37^{\circ} \mathrm{C}$, to measure the residual activity.

Storage stability of the enzyme - Enzyme suspensions were stored at $25^{\circ} \mathrm{C}, 4^{\circ} \mathrm{C},-30^{\circ} \mathrm{C}$ and $-70^{\circ} \mathrm{C}$ for $1,2,5,10,20,30,45$ and 60 days. The residual enzyme activity was determined after each period.

Effect of metal ions, inhibitors and other substances on enzyme activity - Stock solutions of $\mathrm{CaCl}_{2}, \mathrm{HgCl}_{2}, \mathrm{CuSO}_{4}, \mathrm{MnCl}_{2}, \mathrm{FeCl}_{3}, \mathrm{CdCl}_{2}$, $\mathrm{NiSO}_{4}, \mathrm{ZnSO}_{4}, \mathrm{MgCl}_{2}$ and $\mathrm{FeSO}_{4}$ were prepared in phosphate buffer (pH 7.0), and added separately to the reaction mixture in order to obtain a final concentration of $10^{-2}, 10^{-3}, 10^{-4}$ and $10^{-5} \mathrm{~mol} \mathrm{l}^{-1}$. All reagents were purchased from Sigma. Inhibitors such as $p$-chloromercurybenzoate (PCMB) (Sigma) and ethylene diamine tetra-acetic (EDTA) (Sigma) were assayed at the same concentrations as the metal ions. Residual enzyme activity was assayed and expressed as a percentage of the activity determined in phosphate buffer (control).

Reproducibility - All results presented in this paper are the means of three replicate assays.

\section{RESULTS AND DISCUSSION}

The two ß-lactamases isolated from two strains of $N$. gonorrhoeae in this study showed similar behaviour, indicating that they were similar. Therefore further studies were carried out with only one of the isolates.

Under the assay conditions used in this study cell-free extracts of $N$. gonorrhoeae showed an activity of $0.36 \mathrm{U}$ per $\mathrm{mg}$ of protein. The isoelectric point obtained was 5.4, which suggests that this B-lactamase isolated from $N$. gonorrhoeae belongs to the TEM-1 type (Van Embden et al. 1980).
Percival et al. (1977) and Phillips (1976) found similar results in other Neisseria strains.

The effect of the $\mathrm{pH}$ on the enzyme activity is shown in Fig. 1. Optimum $\mathrm{pH}$ was found to be 7.07.2. These results agree with those reported by Livermore and Corkill (1992) who found that $\mathrm{pH}$ values 6.0-7.0 were optimal for ß-lactamase activity in Escherichia coli 976 (ß-lactamase TEM-1).

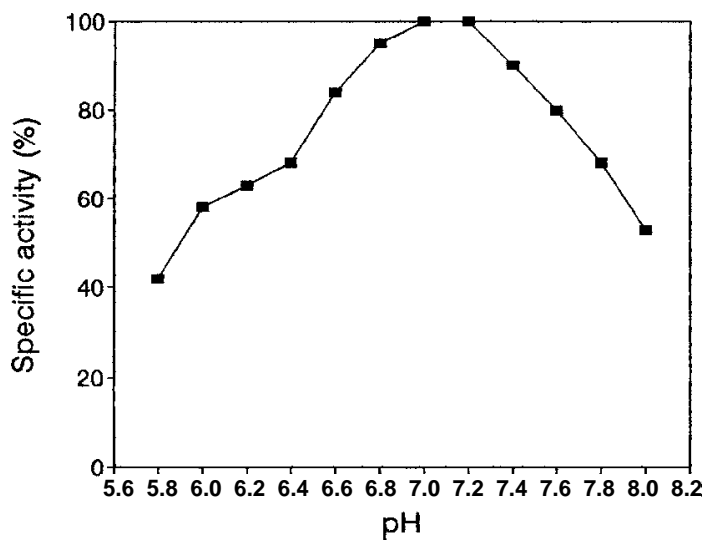

Fig. 1: effect of the $\mathrm{pH}$ on the specific activity (U/mg of enzyme) of b-lactamase from Neisseria gonorrhoeae.

The effect of the temperature on the $\beta$-lactamase activity of the microorganism is shown in Fig. 2. Optimum temperature was $37^{\circ} \mathrm{C}$. Similar behaviour has also been reported by Saino et al. (1982).

The enzyme solutions showed a remarkable stability when kept at low temperatures. The residual enzyme activity of the extracts remained constant for two months throughout storage when kept at $-70^{\circ} \mathrm{C}$ (Fig. 3). The enzyme was totally inactivated at $25^{\circ} \mathrm{C}$ after 20 days of storage. Similar results have been obtained by Edwards and Greenwood (1990) for ß-lactamase isolated from

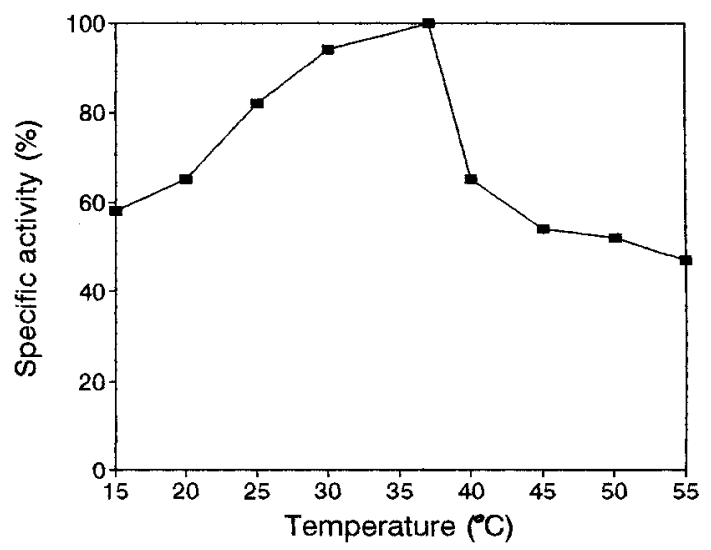

Fig. 2: effect of the temperature on the specific activity (U/mg of enzyme) of b-lactamase from Neisseria gonorrhoeae. Temperatures assayed: $15,20,25,30,37,40,45,50$ and $55^{\circ} \mathrm{C}$. 
Bacteroides, in which case the enzyme retained $100 \%$ activity after storage at $-70^{\circ} \mathrm{C}$ for 10 months. The stability of B-lactamase at low temperatures as found in this work will prove to be of great importance when enzyme purification studies are undertaken.

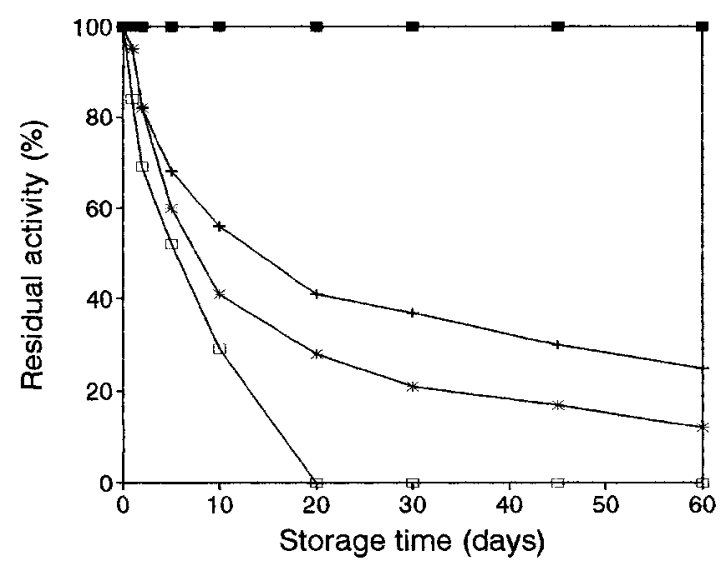

Fig. 3: stability of b-lactamase activity after storage at $-70^{\circ} \mathrm{C}$ (घ), $-30^{\circ} \mathrm{C}(+), 4^{\circ} \mathrm{C}(*)$ and $25^{\circ} \mathrm{C}(\square)$ for $1,2,5,10,20,30,45$ and 60 days.

Fig. 4 shows the results of thermal denaturalization of $\beta$-lactamase activity. Residual activity at $37^{\circ} \mathrm{C}$ after $25 \mathrm{~min}$ is $95 \%$, whereas the enzyme is completely inhibited at $60^{\circ} \mathrm{C}$ after $2 \mathrm{~min}$, demonstrating that the enzyme is thermolabile. Davis et al. (1974) observed that B-lactamase produced by Bacillus cereus lost its activity completely when kept at $50^{\circ} \mathrm{C}$ for $10 \mathrm{~min}$.

The Table shows the effect of cations on the enzyme activity.

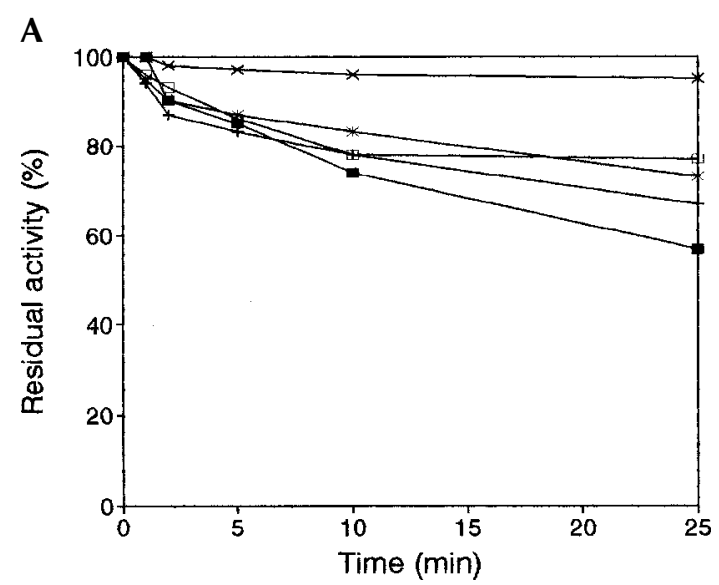

B

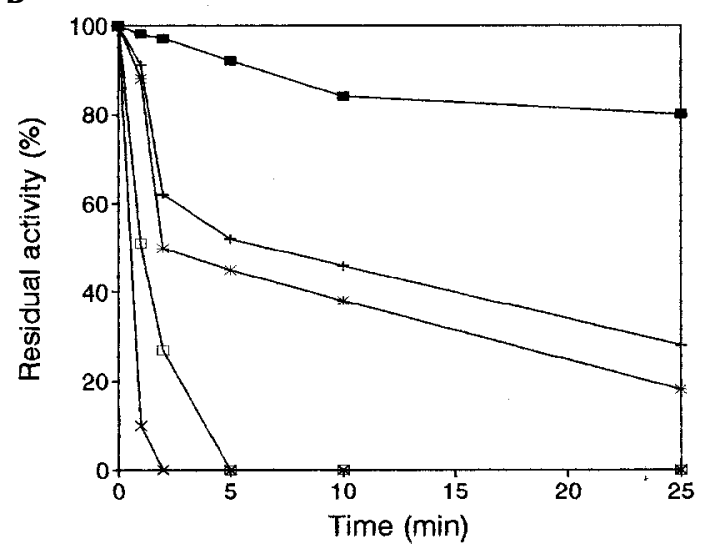

Fig. 4: thermal denaturalization of b-lactamase activity from Neisseria gonorrhoeae. Enzyme extracts were incubated at the temperatures mentioned below for 1, 2, 5, 10 and $25 \mathrm{~min}$. Residual activity was measured after substrate was added and the solution incubated for an additional $15 \mathrm{~min}$ at $37^{\circ} \mathrm{C}$. A: $15^{\circ} \mathrm{C}$ $(\square), 20^{\circ} \mathrm{C}(+), 25^{\circ} \mathrm{C}(*), 30^{\circ} \mathrm{C}(\square)$ and $37^{\circ} \mathrm{C}(\mathrm{x}) . \mathrm{B}: 40^{\circ} \mathrm{C}(\mathbf{\square})$, $45^{\circ} \mathrm{C}(+), 50^{\circ} \mathrm{C}(*), 55^{\circ} \mathrm{C}(\square)$ and $60^{\circ} \mathrm{C}(\mathrm{x})$.

TABLE

Effect of ions and reducing agents on the activity of ß-lactamase of Neisseria gonorrhoeae

\begin{tabular}{|c|c|c|c|c|c|c|c|c|c|}
\hline \multirow[t]{2}{*}{ Effective compound } & \multirow[b]{2}{*}{ Concentration $^{a}$} & \multicolumn{4}{|c|}{$\%$ inhibition } & \multicolumn{4}{|c|}{$\%$ activation } \\
\hline & & $10^{-5}$ & $10^{-4}$ & $10^{-3}$ & $10^{-2}$ & $10^{-5}$ & $10^{-4}$ & $10^{-3}$ & $10^{-2}$ \\
\hline PCMB & & 31 & 65 & 80 & 98 & & & & \\
\hline $\mathrm{HgCl}_{2}$ & & 100 & 100 & 100 & 100 & & & & \\
\hline EDTA & & 100 & 100 & 100 & 100 & & & & \\
\hline $\mathrm{NiSO}_{4}$ & & 3 & 38 & 64 & 82 & & & & \\
\hline $\mathrm{FeSO}_{4}$ & & 2 & 7 & 46 & 50 & & & & \\
\hline $\mathrm{FeCl}_{3}{ }^{4}$ & & 11 & 38 & 57 & 76 & & & & \\
\hline $\mathrm{MnCl}_{2}$ & & 17 & 20 & 44 & 51 & & & & \\
\hline $\mathrm{CdCl}_{2}$ & & 3 & 29 & 53 & 76 & & & & \\
\hline $\mathrm{CaCl}_{2}$ & & 26 & 29 & 30 & 33 & & & & \\
\hline $\mathrm{CuSO}_{4}$ & & 7 & 27 & 45 & 58 & & & & \\
\hline $\mathrm{ZnSO}_{4}^{4}$ & & & & & & 15 & 11 & 8 & 6 \\
\hline $\mathrm{MgCl}_{2}^{+}$ & & 3 & 3 & 3 & 3 & & & & \\
\hline
\end{tabular}

a: concentration in mol $1^{-1}$; PMCB: $p$-chloromercurybenzoate; EDTA: ethylene diamine tetra-acetic acid. 
Among the cations examined, $\mathrm{Hg}^{2+}$ showed complete inhibition of the enzyme at all assayed concentrations, whereas $\mathrm{Ni}^{2+}$ caused an $82 \%$ decrease of the enzyme activity at the highest studied concentration $\left(10^{-2} \mathrm{~mol} \mathrm{l}^{-1}\right) . \mathrm{Hg}^{2+}$ is a strong inhibitor of several $\beta$-lactamase enzymes isolated from different sources, a fact that suggest the presence of thiol groups at the catalytic site. Similar results have been reported by Hirai et al. (1980) who worked with Pseudomonas cepacia and found a $100 \%$ loss of the enzyme activity at a concentration of $3 \times 10^{-3} \mathrm{~mol} \mathrm{l}^{-1}$ of the cation, and by Fujii et al. (1986) for Legionella gormanii. The addition of other divalent cations, e.g. $\mathrm{Fe}^{2+}$ and $\mathrm{Ni}^{2+}$, to the reaction buffer affected the enzyme activity too.

The presence of chelating agents such as EDTA inhibited B-lactamase activity $100 \%$, suggesting that a metal cation is required for its activity. Similar results have been observed by Saino et al. (1982) working with Pseudomonas maltophilia.

Addition of PCMB to the reaction mixture produced a marked inhibition (about 98\%) of Blactamase activity from $N$. gonorrhoeae. The loss of enzyme activity in the presence of PCMB, an agent that oxidizes -SH groups, also supports the idea of the involvement of - $\mathrm{SH}$ groups in the Blactamase activity. The inhibitory effect exerted by PCMB has been reported in earlier studies for strains of $P$. cepacia (Hirai et al. 1980), Bacillus (Sabath \& Finland 1968), Proteus (Imsande et al. 1970) and for Bacteroides fragilis (Yotsuji et al. 1983).

Addition of $\mathrm{Zn}^{2+}$ at a concentration of $10^{-5} \mathrm{~mol}$ $\mathrm{l}^{-1}$ produced a slight stimulation of the enzyme activity, $15 \%$, which agrees with the results found by Sabath and Abraham (1965) for B. cereus.

The results obtained in the present work allowed the identification of B-lactamase in $N$. gonorrhoeae.

As the properties of $\beta$-lactamase of different bacteria vary extremely it is important to study them in each strain. Specific enzymes which inhibit penicillin have been studied and classified. Their properties have been studied in crude extracts from Proteus, Klebsiella , Enterobacter, E. coli, Pseudomonas (Alyffe 1965) and Bacteroides (Edwards \& Greenwood 1990).

Further investigations are necessary to obtain a complete characterization of the $\beta$-lactamases and to be able to classify them, determining their kinetic properties and behaviour with respect to physical and chemical agents. This work provides information that will give us optimal treatments as a benefit, which are important for the implementation of elemental sanitary policies.

\section{ACKNOWLEDGEMENTS}

To Mr Eric Fengler for language advice and drawing of the graphics.

\section{REFERENCES}

Alyffe GAJ 1965. Cephalosporinase and penicillinase activity of Gram-negative bacteria. J Gen Microbiol 40: 119-126.

Amies CR 1969. Sensitivity of Neisseria gonorrhoeae to penicillin and other antibiotics: studies carried out in Toronto during the period 1961 to 1968 . Br J Vener Dis 45: 216-222.

Arya OP, Phillips I 1979. Antibiotic sensitivity of gonococci and treatment of gonorrhea in Uganda. $\mathrm{Br} J$ Vener Dis 46: 149-152.

Ashford WA, Golash RG, Hemings VG 1976. Penicillinase-producing Neisseria gonorrhoeae. Lancet 2: 657-658.

CDC - Centers for Disease Control 1976. Penicillinaseproducing Neisseria gonorrhoeae. Morbidity and Mortality Weekly Rep 25: 261.

CDC - Centers for Disease Control 1977. Gonorrhea and early syphilis cases-United States, 1976. Morbidity and Mortality Weekly Rep 26: 1.

Davis R, Abraham EP, Dalgleish DG 1974. Characterization of beta-lactamase of six species of Bacillus. Biochem J 143: 132.

Edwards R, Greenwood D 1990. Effect of growth conditions and storage on the specific activity of Blactamases of Bacteroides spp. J Appl Bacteriol 69: 421-425.

Fujii T, Sato K, Miyata M, Mitsuhashi S 1986. Purification and properties of a new B-lactamase from Legionella gormanii. Antimicrob Agents Chemother 29: 925-926.

Hirai K, Iyobe S, Inoue M, Mitsushashi S 1980. Purification and properties of a new B-lactamase from Pseudomonas cepacia. Antimicrob Agents Chemother 17: 355-358.

Holmes KK, Karney WW, Harnisch JP, Wiesner PJ, Turck M, Pedersen AHB 1973. Single-dose aqueous procaine penicillin $G$ Therapy for gonorrhea: use of probenecid and cause of treatment failure. $J$ Infect Dis 127: 455-460.

Imsande J, Gillin FD, Tanis RJ, Atherly EG 1970. Purification and properties of beta-lactamase from Proteus morganii. J Biol Chem 245: 2205.

Kaufman RE, Johnson RE, Jaffe HW, Thornsberry C, Reynolds GH, Wiesner PJ, The Cooperative Study Group 1976. National gonorrhea therapy monitoring study: treatment results. N Engl J Med 294: 1-4.

Livermore DM, Corkill JE 1992. Effects of $\mathrm{CO}_{2}$ and $\mathrm{pH}$ on inhibition of TEM-1 and other B-lactamases by penicillanic acid sulfones. Antimicrob Agents Chemother 36: 1870-1876.

Lowry OH, Rosebrough NJ, Farr AL, Randall RJ 1951. Protein measurement with the Folin phenol reagent. J Biol Chem 193: 265-275.

Mahoney JF, Arnold RC, Cutler JC 1945. Penicillin in the treatment of gonorrhea and syphilis. $J$ Venereal Diseases Information 20 (Suppl.): 58-67. 
Martin Jr JE, Lester A, Price EV, Schmale JD 1970. Comparative study of gonococcal susceptibility to penicillin in the United States, 1955-1969. J Infect Dis 122: 459-461.

Matthew M, Harris AM, Marsshall MJ, Ross GW 1975. The use of analytical isoelectric focusing for detection and identification of B-lactamases. J Gen Microbiol 88: 169-178.

Mernes MR, Fiorito S, Galarzar P, Territoriale O 1997. Resistencia plasmídica a Penicilina y Tetraciclina en N. gonorrhoeae en Argentina. P268:161. Libro de Resúmenes del I Congreso Internacional de Infectología y Microbiología Clínica (SADISADEBAC).

O'Callaghan CH, Morris A, Kirby SM, Shingle AH 1972. Novel method for detection of B-lactamases by using a chromogenic cephalosporin substrate. Antimicrob Agents Chemother 1: 283-288.

Percival A, Corkill JE, Rowlands J, Sykes RD 1977. Pathogenicity of and B-lactamase production by Branhamella (Neisseria) catanhalis. Lancet ii: 1175.

Phillips I 1976. B-Lactamase producing, penicillin-resistant gonococcus. Lancet 2: 656-657.

Reyn A 1961. Sensitivity of N. gonorrhoeae to antibiotics. Br J Vener Dis 37: 145-157.

Reyn A 1969. Antibiotic sensitivity of gonococcal strains isolated in South-East Asia and Western Pacific regions in 1961-68. Bull WHO 40: 257-262.

Reyn A, Kotner B, Bentzon MW 1958. Effects of penicillin, streptomycin, and tetracycline on $N$. gonorrhoeae isolated in 1944 and 1957. Br J Vener Dis 34: 227-239.

Reynolds GH, Jaffe HW, Thornsberry C, Zaidi AA, Wiesner PJ 1976. Gonococcal resistance to antibiotics (abstract $\left.n^{\circ} 400\right)$. Program and abstracts of the 16th Interscience Conference on Antimicrobial Agents and Chemotherapy, Chicago. American Society for Microbiology, Washington, D.C.

Sabath L, Abraham EP 1965. Activity of beta-lactamase produced by Bacteroides fragilis. Antimicrob Agents Chemother 392-397.

Sabath L, Finland M 1968. B-Lactamases Bacillus cereus. J Bacteriol: 1511-1513.

Saino Y, Kobayashi F, Inoue M, Mitsuhashi S 1982. Purification and properties of inducible penicillin Blactamase isolated from Pseudomonas maltophilia. Antimicrob Agents Chemother 22: 564-570.

Shockley RK, Coffee EE, Johnston KH 1980. SJ-GC, a modified complete medium for growth of Neisseria gonorrhoeae. J Clin Microbiol 12: 35-38.

Van Embden JDA, Van Klingeren B, Wessens-Kroon M, Van Wijngaarden IJ 1980. Penicilinase-producing Neisseria gonorrhoeae in the Netherlands: epidemiology and genetic and molecular characterization of their plasmid. Antimicrob Agents Chemother 18: 789-797.

Yotsuji A, Minami S, Inoue M, Mitsuhashi S 1983. Properties of novel ß-lactamase produced by Bacteroides fragilis. Antimicrob Agents Chemother 24: $925-$ 929. 
b-lactamase from N. gonorrhoeae - Marta C de Castillo et al. 